\title{
RELATIONSHIP BETWEEN REMITTANCE AND ECONOMIC GROWTH IN NEPAL
}

\author{
Raghu Raj Kaphle*
}

\begin{abstract}
For the period between 1976 and 2017, this study investigates the relation from remittances and trade to economic growth. Study applied time series econometric techniques; unit root, cointegration and error correction mechanism to examine long-run and short-run association between dependent and independent variables. Outcome confirms a long-run relationship between remittance, trade and economic growth. However, no short-run causal relationship exists between remittances and economic growth, but trade showed significant influence even in the short run in GDP for the period of analysis. The paper also discusses about the effective utilization of remittances. It is hoped that the study would be helpful to government and policy makers for domestic policy formation in the area of utilization of remittances and management of migration from Nepal.
\end{abstract}

Keywords: Remittance, economic growth, migration.

\section{INTRODUCTION}

Among the literature, majority of empirical studies dealt with both trade and worker remittances on economic growth (Le, 2008; Abdulbagi, 2016), or the relationship between trade and economic growth (Jenish,2013) or the relationship between remittance and economic growth (Shera \& Meyer, 2013; Uprety, 2017; Giuliano \& Arranz, 2009). Many studies concluded that remittances and trade promote economic growth, however, there is a huge debate about the contribution of trade and worker remittance in economic growth. There are many empirical studies concluding that worker remittances have significant and positive relation with growth (Azam, 2013; Mwangi \& Mwenda, 2015) but many studies are raising the questions on the positive contribution on economic growth, development and income promotion (Uprety, 2016; Detta \& Sarkar, 2014; Pant, 2008). Similarly for the trade openness, it is concluded that trade openness has positive implication on economic growth (Frankel \& Romer, 1999; Metadeen, Metadeen \& Seetanah , 2011; Wacziarg, 2001) and some concludes that the support of trade to growth is not free from debate

* Mr. Kaphle is a PhD Scholar, Dean's Office, Faculty of Humanities and Social Sciences, Kirtipur, TU. 
(Balasubrmanyam, Salisu \& Sapsford, 1996; Yanikkaya, 2003). Most of the time impact depends on political, economic and geographical situations of a country so, however, the issue is no such debatable but universally accepted conclusions are rarely established in this area.

Worker remittances play an important role to start new business, small capital for investment and learn skill for an individual but at national level that would be helpful to formulate capital which would help to promote growth (Giuliano \& Arranz, 2009). For the last two decades the worker remittances have grown rapidly in Nepal, and remittance remained as the major source of foreign currency earning for country (WB, 2018). Regarding trade, that has been increased continuously and very speedy increase after liberalization. Government liberal policy increased both import and export and finally this helped to adopt new technology, get product at low price, increase consumer welfare and help to benefited from spillover effect of trade liberalization.

Despite the abundant literature on remittance, trade and economic growth in many developing countries, there is little empirical work on this subject in Nepal. Some regional and cross sectional countries relations studies were made (Sohn \& Lee 2006; Azam, 2013) however, they are also not free from questions.

This motivates to investigate the relationship between worker remittance, trade and economic growth in Nepal using time series data. Nepal is the developing country in South Asia sending large number of economically active population in foreign employment and receives high volume of remittances. Nepal lies at top five remittance receiving country in terms of percentage of GDP (WB, 2018) and the volume of remittance is substantial in the world figure. Foreign employment is old phenomenon in Nepal but the number of outgoing worker is increasing after the introduction of liberal policy. This has been further aggravated in new century. While talking about trade, Nepal has very liberal policy in financial, trade and other economic areas. Nepal Government introduced varies liberal economic and financial policy from the mid-1970s (introduction industrial policy, regional development concept etc) which makes trade easier. The volume of trade was increasing continuously and the volume of import is higher than volume of export. The volume of trade is around fifty percent of GDP and the ratio of import is more than ninety percent in Nepal (GoN/MoF, 2018). Contrasting the high volume of remittances and highly liberalized economy, Nepal is suffered from low economic growth and high unemployment rate. 
This situation inspired to conduct research on impact of worker remittance and trade on economic growth of Nepal.

In addition to that, this study can contribute to the existing literature which provides either conflicting results concerning the relationship between variables. Government of Nepal is introducing the policy, law and institutional set up for the effective utilization of remittance in productive activities (eg; foreign employment policy, foreign employment act, department, board etc). Similarly Nepal government is giving high importance to trade liberalization. In these circumstances this study should be helpful to provide policy feedback to the Government of Nepal.

The main objective of this study is to examine the relationship between worker remittance and economic growth in Nepal. This paper has a unique contribution to the literature in the context of Nepal being an important attempt to examine the impact of worker remittances and trade on GDP by using the time series data for the period 1976 to 2017 using rigorous econometric techniques.

\section{LITERATURE REVIEW}

Economic growth is the major indicator of development throughout the world so many scholars put their contribution to explain about economic growth theoretically and empirically. Many researchers explained about the contributor of growth. Labor migrating is growing business in the world and that become a major contributor for growth and development especially in developing countries. This has become a major global phenomenon and United Nation introduced Global Forum on Migration and Development (GFMD) and Global Compact on Migration (GCM) to highlight the role of migration and remittance on development. Now a day there is huge discourse about the contribution of labor migration to growth. Manufacturing trade is another major variable which contribute economic growth, this is taken as the key factor for development. It is argued that the positive effects of international trade on economic growth were first pointed out by Adam Smith (Afonso, 2001). Many international (WTO) and regional (SAEAN, EU, SAARC, etc) and bilateral initiatives were introduced to promote trade and to achieve higher growth. It is believed that more trade would be helpful for more earning. Out of those literatures only few are taken as reference to this study. 


\section{Remittance Growth Relation}

With the growing in openness and friendship in the world, migration is increasing regularly. Now a day this is taken as the one of the largest industry in the world (Czaika \& Hass, 2014). There is both North to South and South to North movement for better opportunity. This movement generates large volume of production and income in the world. The past decade was marked by the increasing role of remittances in total international capital flows. For many developing countries, remittances represent a significant part of international capital flows, exceeding exports revenues, foreign direct investment and aid (IMF, 2005). Remittance becomes a great matter of discussion whether it is doing well for economic growth? There we can find both arguments and empirical findings about it.

Remittances have become a very popular issue in international literature of finance in these decades because their volume and their potential to reduce poverty and stimulate economic growth in developing countries. Globally, remittances reached $\$ 613$ billion. Remittances to South Asia increased by 5.8 percent in 2017 after a slowdown of -6.1 percent in 2016 (WB, 2018).

A study conducted by European Parliament Policy Department (2014) concludes that remittances is more sustainable source of foreign currency for developing countries than other capital inflows like foreign direct investment, public debt, official development assistance. But remittance development relation is complex, especially with regards to the movement of people, which contributes to the spread of global interdependence at all levels; social, economic and political. Remittances have a positive impact on growth and this impact increases at high levels of remittances relative to GDP (Mayer \& shera, 2017). The positive relation between remittance and growth is for both absolute and relative GDP (Goschin, 2014). A study of 36 African countries by Fayissa and Nsiah (2010) followed the same fact that remittance positively impacts economic growth by providing alternative way to finance investment and helping to overcome liquidity constraints. Remittance is an important source of private capital flow, and inflow of capital have multiplier effect on different macroeconomic indicators such as poverty alleviation, saving mobilization, increase investment, capital accumulation and other many areas which ultimately helps to promote economic growth (Akter, 2016). In the long run remittances have positive contribution on economic growth per capita (IMF, 2005). 
Economically motivated migrants can set in motion 'virtuous circle' as when young workers who would have been unemployed at home find jobs abroad, send home remittances that reduce poverty and are invested to accelerate economic and employment growth who return with new skills and technologies that lead to productive activities (Martin, 2004). Remittance is helpful to promote growth in less financially developed countries (IMF, 2005). In many developing countries, remittances of workers have become an important source of external financing. The migration and remittances will continue to be an important part of the economic political and social development of developing country (Topxhiu \& Xhelili, 2016). Another conclusion is more or less similar, about 82 percent migrants originated from developing countries and their remittances amount to about 592 billion dollars in 2014, which represents an essential source of foreign exchange in these countries and a very important instruments to reduce poverty. Economies with underdeveloped financial system remittances eliminate barriers and credits, and serve as a substitute for financial development by improving the allocation of capital and thus accelerating economic growth (Giuliano \& Arranz, 2009). Remittance can make great change in health education and other social indicators which help to achieve economic growth.

In this regard, Azam (2013) empirically examine the relationship of worker remittances with economic growth in four developing countries in South Asia and found the existence of a significant and the positive relationship between migrant worker remittance and economic growth. The study look for causality between remittance and economic growth in Kenya, economic growth is found significantly supported by international remittances (Mwangi \& Mwenda, 2015). Remittances at the same time are also associated with increased investment in education, entrepreneurship and health of their recipients and finally affect economic growth of the country.

There is heavy debate about the impact of remittance on GDP. Many studies concluded that remittance have negative impact to economic growth of receiving counties. Different countries have different remittance utilization capacity, economic stability, institutional arrangement and political situation that would play an important role to produce desired impact on economic growth. Remittance may bring growth, development and Balance of Payment crisis if that is used for conspicuous consumption or unproductive activities (Datta \& Sarkar, 2014). While remit receiver depends on easy money causing to reduce their effort and their less 
participation on labor market. A study based on Nepal, Uprety (2017) did not found the association between remittances and investment but found that there is positive relation with consumption. Remittance ultimately reduce agro product, increase consumption and no change in investment means remittances has adverse effect on economic growth. Remittances have a negative effect on developing countries when people receive remittance the receiver will become economically inactive in the sense of production, which reduce the work performance and productivity and ultimately reduce the workforce (Chami, Fullenkamp \& Jahjah, 2003; Zogjani \& Pantina, 2014). A single country study based on Turkey, Karagozk (2009) found that remittance have a negative impact on economic growth. Some country benefits in the short run and some in the long run. Jawaid and Raza (2012) examined the short run and long run relationship and robustness of workers' remittances and economic growth in China and Korea, and concluded that positive relation in Korea and inverse relation in China. The most debatable part is the long-run implication of remittance on economic growth.

Benefit of remittance based on the utilization plan, capacity and situation of a particular country. Sharaf (2014) study the long run causal link between remittances and output in Egypt for the period 1977-2012 and concluded that remittances and GDP are cointegrated with a statistically significant positive causality running from remittances to output, while output is found not to be a long run forcing factors of remittance in Egypt. If government uses remittance efficiently that will promote growth. Similarly a study based on Nepal, Pant (2008) suggest that workable policy or programs needs to be introduce by government to encourage the utilization of remittance for productive sector to promote long run economic growth. Country with less financial development will get benefit from remittance then the country which is financially developed (Giuliano \& Arranze, 2009).

\section{Trade Growth Relation}

Several prior studies examined the relationship between trade openness and growth by applying different methods and concluded that openness benefits to economic growth (Frankel \& Romer, 1999). Empirical analysis reached to the conclusion that trade openness has positive and significant impact on economic growth (Wacziarg, 2001; Sachs \& Warner, 1995). Another research introduce 'Trade structure' variable which shows strong evidence of positive effect on growth (Shon \& Lee, 2006). 
Trade openness has positive impact on economic growth in the long run but all countries are not getting same kind of benefit (Mangir, Kabaklarli \& Ayhan, 2017). If the country is adopting good open door policy that would be helpful to get long-run economic benefit from open trade (Dristsaki, Dristsaki \& Adamopoulos, 2004; Andersen \& Babula, 2008).The relation does not limited only in the long run, many countries are getting benefit from trade liberalism both in the short run and in the long run (Chandrashekar, Sampath \& Chittedi, 2018; Matadeen, Matadeen \& Seetanah, 2011).

Only implementation of trade openness policy is not sufficient to get higher economic growth. The emerging economies benefited more from removing trade barrier if they explore new markets (Weisbort \& Baker, 2002).Trade openness will help to transfer technology and knowledge, rich countries benefits more than poor countries because poor countries have no ability to adopt advance technology and transfer knowledge (Dowrick \& Golley, 2004; Grossman \& Helpman, 1991). Liberalization promotes growth and such output growth in pre-liberalization period is lower than that in post liberalization period (Parikh \& Stirbu, 2004).

The quality and variety of product in international trade has very important meaning, counties exporting higher quality with a variety of product in international trade grows more rapidly (Burdon, Mouel \& Visil, 2012). There is a bidirectional relation between economic growth and trade liberalism. The study conducted by Soukhakian (2007) and Giraldo \& Canas (2016) observed that the causality relation between economic growth and openness and found a long-run equilibrium relationship between financial development, trade and economic growth. Trade within the trade bloc is more important.

The issue of trade liberalization and its relation to economic growth is a more debatable matter (Rodriguez \& Rodrik, 2000). Some time trade openness has no any relation to economic growth, the relation is undefined (Vimvakidis, 2002). Kahya (2015) shows that the import was one of the significant determinants of economic growth where as export did not have an important impact on economy. Small economies, which are often highly open to trade, argued that the positive and negative effects of openness may offset each other Easterly and Kraay (2000) and developing countries have no capacity to get the benefit (Yanikkaya, 2003). Least developed countries (LDCs) will have high volatility that can be reduced by export diversification (Haddad, Lim \& Saborawski, 2010). 


\section{REMITTANCE, TRADE AND ECONOMIC GROWTH IN NEPAL}

Migration is intertwined with geopolitics, trade and cultural exchange, and provides opportunities for States, businesses and communities to benefit enormously. In general, immigration adds workers to the economy, thus increasing the gross domestic product (GDP) of the host country (International Migration Report, 2018). Since the 1970s, the oil-rich Gulf countries have been a major destination for a vast number of temporary labour migrants from South Asia. While India and Pakistan were initially the major origin countries of labour to Gulf countries, the origin of migrant workers has since diversified, attracting workers from Sri Lanka, Nepal and Bangladesh. There are millions of Bangladeshi and Nepalese labour migrants working in India, for example, primarily in the informal sector as construction laborers and domestic workers (IOM, 2018).

The history of labor migration from Nepal dates back to the period of unification, more than 300 years ago (Piya \& Joshi, 2016). Much of the history of labor migration for foreign employment from Nepal is characterized by the outflow to India, at least up to the mid 1970s. Then suddenly new destinations emerged with the intensification of globalizing dynamics and the boom in the oil industry that started in the Middle East in the 1970s (IOM, 2018).

A historical turn in the migration pattern came with the restoration of democracy in Nepal in 1990. The democratically elected government in 1992 embarked on a journey of economic liberalization and made official moves to a market economy, which also encouraged out-migration. The liberalization on mobility as well as the economy after the 1990s coupled with the rapidly increasing labor demand in the Middle East countries (GoN/MoLE, 2014).

As in many other developing countries, remittance played an important role in Nepal. World Economic Outlook of WB report (Migration and Development Brief 29) shows that Nepal lies in top five highest remittance receiving country in terms of GDP. Nepal remittance receiving growth rate is so high that has been presented in Table-1. Nepal is sending people in about 170 countries (Department of Foreign and Employment, DoFE) mostly Nepal receives high remittance from Qatar, Saudi Arabia, Malaysia and other Gulf countries and India. 
Table 1: Remittances and FDI as Percent of GDP

\begin{tabular}{|l|c|c|c|c|c|c|c|c|}
\hline Year & 1993 & 1997 & 2001 & 2009 & 2013 & 2015 & 2016 & 2017 \\
\hline Remittances & 0.7 & 0.5 & 1.3 & 19.2 & 30.4 & 33.4 & 32.7 & 32.0 \\
\hline FDI & 0.0 & 0.2 & 0.2 & 0.3 & 0.4 & 0.3 & 0.5 & 0.9 \\
\hline
\end{tabular}

Source: WDI, 2018

This shows that as percentage of GDP Nepal is receiving very high remittance. FDI is very low in comparison to remittances. This indicates that remittance is the major source of foreign currency financing.

Nepal is getting liberal from the mid of 1970s (Khanal, Rajkarnikar, Acharya, \& Upreti, 2005). During that period the volume of trade is increasing regularly. To promote trade Nepal become a member of WTO in 2004 , it actively participated in international and regional forums and there are many bilateral initiatives to promote trade. Both import and export is increasing (GoN/MoF, 2018 ) regularly after liberalization.

Table 2: Total Trade, Export and Import (all current value series).

\begin{tabular}{|l|c|c|c|c|c|c|c|c|c|}
\hline Year & 1976 & 1985 & 1991 & 2000 & 2006 & 2012 & 2015 & 2016 & 2017 \\
\hline $\begin{array}{l}\text { Total Trade } \\
(\mathbf{1 0} \text { million) }\end{array}$ & 317 & 1048 & 3061 & 15833 & 23401 & 53593 & 86000 & 84372 & 106316 \\
\hline Percent Export & 37 & 26 & 24 & 31 & 26 & 14 & 10 & 8 & 7 \\
\hline Percent Import & 63 & 74 & 76 & 69 & 74 & 86 & 90 & 92 & 93 \\
\hline
\end{tabular}

Source: WDI, 2018

The volume of trade in increasing continuously and at the same time import is swelling alarmingly during the period.

\section{METHODOLOGY AND ANALYSIS}

This paper uses a log-log econometric model to test cointegration and causality from remittances to economic growth. It is possible that there could be unidirectional causality from remittances to economic growth, and it is also possible that there is no dependency of GDP in remittance (Baker et al. 2015). To test the significant influence of remittance in economic growth, the analysis yields a general model as;

$$
\ln Y_{t}=\beta_{0}+\beta_{1} \operatorname{lnRem}_{t}+\beta_{2} \sum_{i=1}^{n} \ln X_{i t}+u_{i}
$$

Where, ' $I n$ ' represent natural $\log$, ' $\mathrm{Y}$ ' stand for GDP, $\beta_{\text {is }}$ are coefficients, 'Rem' stand for remittance, ' $X_{i s}$ ' are complementary series for 
growth (here only trade is represented by term) and $u_{i}$ represent error term. And the equation for this study becomes;

$$
\ln Y_{t}=\beta_{0}+\beta_{1} \operatorname{lnRem}_{t}+\beta_{2} \ln \text { Trade }_{t}+u_{i}
$$

To complete the econometric procedure, unit root test was performed for stationary to avoid spurious regression. In a second step, to determine the long run association, series were tested for cointegration. The cointegration test result determined the presence of correction term in the model and then used in the next step. In this third step, if the series are cointegrated of the same order, the error-correction model (ECM) is applied to find the relationship. Following the Engle-Granger approach, residual series generated from following equation is tested for presence of cointegraion in the model.

$$
\hat{u}_{i}=\ln Y_{t}-\left(\beta_{0}+\beta_{1} \operatorname{lnRem}_{t}+\beta_{2} \ln \operatorname{Trade}_{t}\right) \text {. }
$$

If there is no cointegration among series in step 2, the multiple regression method with variables in first difference is applied to test relationship as the standard model (Toda and Phillips, 1993). Further residual tests were performed for the accuracy of prediction of the model.

To analyze the relationship between remittances and economic growth, this paper uses annual time series data from 1976 to 2017 from Nepal. To this study gross domestic product (GDP) is used as proxy of economic growth. GDP is taken as dependent variable. Remittance and trade is independent variables and remittance is the interest variable to this study. Data are received from Central Bureau of Statistics (CBS) Nepal. Remittances data of Nepal is publicly available only from 1993 in WDI and from 2001 in CBS. But, Upreti (2017) and Giuliano and Ruiz Arranz (2009) constructed data for the period 1976 to 2002. To mitigate data gap, this study also consider data from Upreti (2017). All data series are in nominal form and GDP deflator is used to convert in constant form taking 2010 as base year. Table 3 shows the descriptive statistics of the variables used in our analysis. The data series covers 42 years.

Table 3: Descriptive Statistics of Variables

\begin{tabular}{|l|c|c|c|c|c|}
\hline Variable & Mean & Std. Dev. & Minimum & Maximum & No. Obs. \\
\hline $\begin{array}{l}\text { GDP (ten } \\
\text { million LCU) }\end{array}$ & 76041.35 & 70963.32 & 4664.95 & 262307.7 & 42 \\
\hline $\begin{array}{l}\text { Remittance (ten } \\
\text { million LCU) }\end{array}$ & 12333.18 & 19733.6 & 57.57503 & 66074.35 & 42 \\
\hline $\begin{array}{l}\text { Trade (10 } \\
\text { million LCU) }\end{array}$ & 28202.59 & 29054.72 & 856.5089 & 115487.8 & 42 \\
\hline
\end{tabular}




\section{Unit Root Test}

Stationary test is prerequisite for both causality and cointegration (Gyanwaly, 2012). It is essential to test for non-constant mean, variance and auto-covariance over time i.e. non-stationary for all series those considered in the analysis. If a non-stationary series becomes stationary after differentiating ' $n$ ' times, then the series is said to be integrated of order ' $n$ '. This is the first step in finding causation between variables in time series econometrics and for the causality, series should be free from time trend (Stock and Watson, 1989), and as majority of macroeconomic series are non-stationary (Nelson \& Plosser, 1982). When series are found integrated of the same order, the next step is to examine for the presence of cointegration i.e. the long run association between variables. To verify this preliminary condition, series of GDP, remittance and trade were tested for a unit root by using augmented Dickey-Fuller (ADF) test (Dickey \& Fuller, 1979).

\section{Time Series Cointegration Test}

All series; economic growth, remittances and trade are said to be cointegrated when all series are found to be integrated in the same order. For the robustness of cointegration test, Engle-Granger method of cointegration (Engle \& Granger, 1991) based on autoregressive representation is applied here. For this computed test statistic is compared with Engle-Granger five percent critical value.

\section{Error Correction Mechanism (ECM)}

To examine the relationship between GDP and remittances the ECM mechanism is used in this paper, as cointegration tests detailed in previous section revealed that the variables in our analysis are cointegrated of order one, i.e. the long-run causality. Engle-Granger critical value indicates that there exists long run associationship in the model, based on that, equilibrium-correction mechanism (ECM) is used to test the relationship in equation (2). The ECM can examine long-run causal relationships based on the error-correction term ECT (-1) and can be express as:

$$
\Delta \ln Y_{t}=\beta_{0}+\beta_{1} \Delta \operatorname{lnRem}_{t}+\beta_{2} \Delta \ln \text { Trade }_{t}+\beta_{3} \text { Ect }_{t-1}+v_{i}
$$

Where $\Delta$ denote the first difference of variables which capture their short-run disturbances over periods $\mathrm{t}=1,2, \ldots, \mathrm{T} ; v_{i}$ is the white noise error term and $E c t_{t-1}$ is the error correction term (ECT) that is resultant from the long-run cointegration association. 


\section{Long-Run and Short Run Relationship}

The coefficient of ECT explains about the long-run relationship among dependent and independent variables and indicates the speed of adjustment. Size of coefficient of the ECT informs about deviation of the dependent variables from the long run equilibrium and significance of coefficient suggests that in the long-run mechanism is deriving dependent variable in equilibrium relationship. The rule of thumb is that coefficient of the ECT should be significant and a negative number between 0 and -1 , indicates about number of period the equilibrium is restored. At the same time, Short-run relationship is tested by evaluating the significance of the coefficients of the independent variables.

\section{RESULTS}

All three series are tested for unit root by using augmented dickey fuller (ADF) test to check the stationary of datasets in terms of whether they are integrated of the same order (Granger, 1988). Table 4 represents the results of the ADF test on stationary of the GDP, trade and remittances. Results of the two tests indicate that all three series are non-stationary at levels but are stationary in first differences.

Table 4: Unit Root Test

\begin{tabular}{|l|l|c|c|}
\hline Variables & Deterministic & Level & First Difference \\
\hline \multirow{2}{*}{ LnGDP } & Intercept & -1.16 & $-5.61^{* * *}$ \\
\cline { 2 - 4 } & Intercept \& Trend & -1.02 & $-5.59^{* * *}$ \\
\hline \multirow{2}{*}{ LnREMIT } & Intercept & 0.10 & $-5.73^{* * *}$ \\
\cline { 2 - 4 } & Intercept \& Trend & -2.13 & $-5.72^{* * *}$ \\
\hline \multirow{2}{*}{ LnTrade } & Intercept & -1.19 & $-5.61^{* * *}$ \\
\cline { 2 - 4 } & Intercept \& Trend & -1.07 & $-5.63^{* * *}$ \\
\hline
\end{tabular}

Note: Lag length based on Schwarz information criterion (SIC) ${ }^{*} \mathrm{p}<0.10,{ }^{* *} \mathrm{p}<0.05$ and ${ }^{* * *} \mathrm{p}<0.01$, these represent significant $\mathrm{p}$ values.

As all the series are stationary in first difference, here Engle-Granger cointegration tests should be performed to investigate cointegration among them. The result of cointegration test is shown in Table 5. ADF test statistics is presented in table with Engle-Granger critical value at five percent level significance. As absolute value of t-test statistics is greater than absolute value of Engle-Granger five percent critical value, indicate residuals from OLS estimation are stationary i.e. there is no unit root in the residual series at level finally suggest for long run relationship between GDP and other independent variables. 
Table 5: Engle-Granger Cointegration Test

\begin{tabular}{|c|c|c|c|c|}
\hline & $\begin{array}{c}\text { Engle Critical } \\
\text { Value 5\% }\end{array}$ & t-stat & R-square & D-W stat \\
\hline ECT1 & -3.91 & -5.6228 & 0.6780 & 2.009 \\
\hline
\end{tabular}

Note: ${ }^{*} \mathrm{p}<0.10, * * \mathrm{p}<0.05$ and $* * * \mathrm{p}<0.01$, these represent significant $\mathrm{p}$ values.

The error correction term from equation (3) not only informs about the long-run relationship among variahle series but also tells about the significance of the speed of adjustment, ${ }^{\beta_{3}}$ the coefficient of correction term in equations (4). A significant value between 0 and -1 suggest convergence of deviation from equilibrium in the long-run (Baker, Merkert \& Kamruzzaman, 2015). The residual from equation (4) follows CLRM assumptions for the model. Table 6 summarizes the outcome of ECM of Remittances-GDP relationships. The coefficient of ECT is negative and significant, indicate that there is a long run relationship between remittance and GDP. Probability and coefficient of the error correction term indicate that previous year disequilibrium is adjusted at the rate $48.48 \%$ annually. Coefficient of remittance shows no significant effect on GDP of the country, however trade showing influencing role for the country.

Table 6: OLS Estimate of ECM (Dependent Variable: $\triangle$ LNGDP)

\begin{tabular}{|c|c|c|}
\hline Variables & Coefficient & Probability \\
\hline$\triangle$ LNREM & 0.0388 & 0.1522 \\
\hline$\triangle$ LNTRADE & $0.6376 * * *$ & 0.0000 \\
\hline ECT(-1) & $-0.4848 * * *$ & 0.0032 \\
\hline Constant & 0.156 & 0.1311 \\
\hline \multicolumn{2}{|c|}{ R-square } & 0.8088 \\
\hline \multicolumn{2}{|c|}{ D-W Stat } & 1.6059 \\
\hline \multicolumn{2}{|c|}{$\begin{array}{l}\text { F-Stat } \\
\text { (Prob.) }\end{array}$} & $\begin{array}{c}52.1758 * * * \\
(0.0000)\end{array}$ \\
\hline
\end{tabular}

Note: ${ }^{*} \mathrm{p}<0.10, * * \mathrm{p}<0.05$ and $* * * \mathrm{p}<0.01$, these represent significant $\mathrm{p}$ values.

\section{CONCLUSION}

This paper analyzes the relation between remittances received and economic growth in Nepal. Unit root, cointegration and error correction technique of econometric procedure are applied for examination. Outcome 
from estimation suggest that there is a long run association between remittance, trade and economic growth. Moreover, finding indicates that the relation between remittance and economic growth is not significant in the short run. As results suggest an absence of short-run causation from remittances to GDP, but there exist long-run relationship between economic growth and remittance earning. This implies that the policy maker should implement appropriate policy to invest in infrastructure frameworks to accommodate the expected outcome. Further study should be done, including time varying covariates (Ex: FDI, industrialization ect) to improve the model presented here.

\section{REFERENCES}

Abdelbagi, E. (2016). Migration, remittances, trade openness and economic growth in Africa: GMM technique. Journal of Global Economics, $4(2)$.

Afonso, O. (2001). The impact of international trade \& economic growth. Faculdade de Econmia do Porto.

Akter, S. (2016). Remittance inflows and its contribution to the economic growth of Bangladesh. The Journal of Modern Society and Culture, (62).

Andersen, L., \& Babula, R. (2008). The link between openness and long run economic growth. Journal of International Commerce and Economics.

Azam, M. (2013). The role of migrant workers' remittances in fostering economic growth: the four Asian developing countries' experiences. International Journal of Social Economics, 42(8), pp. 690 -705.

Baker, D., Merkert, R., \& Kamruzzaman, M. (2015). Regional aviation and economic growth: cointegration and causality analysis in Australia. Journal of Transport Geography, (43), pp. 140-150.

Balasubramanyam, V.N., Salisu, M.A., \& Sapsford, D.(1996). Foreign direct investment and growth in EP and IS countries. Economic Journal, (106), pp. 92-105.

Burdon, M.H., Mouel, C.L., \& Visil, M. (2013). The relationship between trade openness and economic growth: some new insights on the openness measurement issue. Agro Campus-Quest, UMR 1302.

Chami, R., Fullenkamp, C., \& Jahjah, S. (2003). Are immigrant remittances flows a source of capital for development? IMF Working Paper, (189). 
Chandrashekar, R., Sampath, T., \& Chittedi, K.R. (2018). Financial development, trade openness and economic growth in India. Theoretical and Applied Economics, 25(1), pp. 113-124.

Czaik, M., \& Hass, H.D. (2014). The globalization of migration: has the world become more migratory. International Migration Review, $48(2)$.

Datta, K., \& Sarkar, B. (2014). Relationship between remittances and economic growth in Bangladesh: an Econometric Study. Bangladesh Development Research Working Paper Series, (19).

Dickey, D. A., \& Fuller, W. A. (1979). Distribution of the estimators for autoregressive time series with a unit root. Journal of the American statistical association, 74(366a), pp. 427-431.

Dowrick, S., \& Golley, J. (2004). Trade openness and growth: who benefits? Oxford Review of Economic Policy, (20), pp. 38-56.

Dritsaki, M., Dritsaki, C., \& Adamopoulos, A. (2004). A causal relationship between trade foreign direct investment \& economic growth in Greece. American Journal of Applied Sciences, 1(3).

Easterly, W., \& Kraay, A. (2000). Small states, small problems? income, growth, and volatility in small states. World Development, 28 (11), pp. 2013-2027.

Engle, R., \& Granger, C. (1991). Long-run economic relationships: readings in cointegration. Oxford University Press.

Fayissa, B., \& Nsiah, C. (2010). The impact of remittances on economic growth and development in Africa. The American Economist.

Frankel, J.A., \& Romer, D.H. (1999). Does trade cause growth? American Economic Revie,. 89(3), pp. 379-399.

Giraldo, A., \& Canas, J. (2016). International trade and economic growth: causality relations within NAFTA. Vniversitas Economica, (015302).

Giuliano, P., \& Ruiz-Arranz, M. (2009). Remittances, financial development, and growth. Journal of Development Economics, 90(1), pp.144152.

Goschin, Z. (2014). Remittance as an economic development factor: empirical evidence from the CEE countries. ScienceDirect, Procedia Economics \& Finance, (10), pp. 54-60. 
GoN/MoLE. (2014). Labor migration for employment: a status report for employment. Ministry of Labor and Employment.

GoN/MoF. (2018). Economic survey. Ministry of Finance.

Granger, C. W. (1988). Some recent development in a concept of causality. Journal of econometrics, 39(1-2), pp.199-211.

Grossman, G. M., \& Helpman, E. (1991). Innovation and growth in the global economy. Cambridge: MIT Press.

Gyanwaly, R.P. (2012). Causal relationship between money, price and income in Asian countries. The Economic Journal of Nepal, 35(1).

Haddad, M. E., Lim, J. J., \& Saborowski, C. (2010). Trade openness reduces growth volatility when countries are well diversified. World Bank Policy Research WP, (5222).

IMF. (2005).World economic outlook, globalization and external imbalances.

IMF. (2005). Remittances, financial development \& growth. IMF, WP, 05(234).

IOM. (2018). World migration report. International Organization for Migration.

Jawaid, S.T., \& Raza, S.A. (2012). Workers' remittances and economic growth in China and Korea: an empirical analysis. Mnunich Personal Repec Archive.

Jenish, N. (2013). Regional rrade and economic growth in the CIS region. University of Central Asia. Institute of Public Policy and Administration, WP, (21).

Johansen, S., \& Juselius, K. (1990). Maximum likelihood estimation and inference on cointegration-with applications to the demand for money. Oxford Bulletin of Economics and statistics, 52(2), pp. 169210.

Karagoz, K. (2009). Workers' remittances and economic growth: Evidence from Turkey. Journal of Yasar. University 4 (13), 1891-1908.

Khaya, M. (2011). An analysis of the relationship between foreign trade and economic growth in Turkey over the period 1980-2009. Lund University, School of Economics \& Management. Unpublished Thesis in Master in Economics.

Khanal, D.R., Rajkarnikar, P.R., Acharya, K.P., \& Upreti, D.R. (2005). Understanding reforms in Nepal: political economy and institutional 
perspective. Institute for Policy Research and Development, Kathmandu.

Le, T. (2008). Trade, remittances, institutions and economic growth. Macroeconomic Research Group. ISSN 1833-4474.

Mangir, F., Kabaklarli, E., \& Ayhan, F. (2017). An analysis of the relationship between trade openness and economic growth: evidence for ten African countries. Journal of Management and Economic Research, 15(1).

Martin, P. (2004). Migration and development: toward sustainable solutions. Discussion Paper. International Institute for Labor Studies, Geneva.

Matadeen, J. Matadeen, J., \& Seetanah, B. (2011). Trade openness and economic growth evidence from mauritius. ISSN:16941225.

Meyer, D. \& Shera, A. (2017). The impact of remittance on economic growth: an econometric model. Science Direct, EconomiA , (18), pp. 147-155.

Mwangi, B.N., \& Mwenda, S.N.(2015). The effect of international remittances on economic growth in Kenya. Macroeconmics and Macroeconomcs, 3(1), pp. 15-24.

Nelson, C. R., \& Plosser, C. R. (1982). Trends and random walks in macroeconomic time series: some evidenceandimplications.Journal of monetary economics, 10(2), pp. 139-162.

Pant, B. (2008). Mobilizing remittances for productive use: A policy oriented approach. $N R B$ Working Paper, $N R B / W P / 4$.

Parikh, A., \& Stirbu, C. (2004). Relationship between trade liberalization, economic growth and trade balance: an econometric investigation. HWAA Discussion PAPER (282). Hamburg Institute of International Economics.

Piya, L., \& Joshi, N.P. (2016). Migration and remittances in Nepal: a review of the push-pull factors and socioeconomic issues. Journal of contemporary India Studies: Space and Society, Hiroshima University, (6), pp. 41-53.

Policy Department. (2014). The impact of remittances on developing countries. European Parliament. EXPO/B/DEVE/2013/34. 
Rodriguez, F., \& Rodrik, D. (2000). Trade policy and economic growth: a skeptic's guide to the cross-national evidence. National Bureau of Economic Research, (7081).

Sachs, J. D., \& Wanner, A. (1995). Economic reform and the process of global integration. Brookings Papers on Economic Activity, pp. $1-118$.

Sharaf, M. (2014). The remittance-output nexus: empirical evidence from Egypt. Economic Research International, ID 965240.

Shera, A., \& Meyer, D. (2013). Remittance and their Impact on economic growth. Periodica Polytechnica, Social \& Management Sciences.

Sohn, C.H., \& Lee, H. (2006). Trade structure and economic growth: implication to East Asia. Centre for International Trade Studies. CTIS WP/2006-01.

Toda, H.Y., \& Phillips, P.C. (1993). Vector autoregressions and causality. Econometrica, 61( 6), pp.1367-1393.

Topxhiu, R., \& Xhelili, F. (2016). The role of migrant workers remittacnes in fostering economic growth: the Kosovo experience. The Romanian Economic Journal, 19(61).

Uprety, D. (2017). The impact of remittances on economic growth in Nepal. Journal of Development Innovations, 1(1), pp. 114-134.

Vamvakidis, A. (2002). How robust is the growth-openness connection? historical evidence. Journal of Economic Growth, (7), pp. 57-80.

Wacziarg, R. (2001). Measuring the dynamic gains from trade. The World Bank Economic Review, (15), pp. 393-429.

WB. (2018). Migration and development brief 29. Migration and Remittances: Recent Development Outlook.

Weisbrot, M., \& Baker, D. (2002). The relative impact of trade liberalization on developing countries.

Yanikkaya, H. (2003). Trade openness and economic growth: a cross country empirical investigation. Journal of Development Economics, 72(1), pp. 57-89.

Zogjani, J., \& Pantina, M.B. (2014). The role of impact of remittances on the economic growth: Kosovo case study. Iliria International Review, (2). 